\title{
PENGGUNAAN SENSUALITAS DALAM KOMUNIKASI PEMASARAN SEBUAH STUDI KASUS PADA PARIWARA TELEVISI IKLAN KONDOM SUTRA
}

\author{
Yusnaidi $^{1}$, Cut Devi Maulidasari ${ }^{2}$, Fajri Hadi ${ }^{3}$, Fatmayanti ${ }^{4}$, Muhammad Rahmat \\ Hidayat $^{5}$ \\ 1,2,3,4,5 Fakultas Ekonomi Universitas Teuku Umar \\ Email Korespondensi : yusnaidiyahya@gmail.com
}

\begin{abstract}
This research is designed to anylize the used of women sexuality at tv advertising. It is a fact that tv ad is one of the effective marketing communication tools to promotes a product and builds corporate image. However there are a lot of misconduct in implementing tv ads to persuade consumers by showing conversations and scenes with a lot of sexual images. Sexual images in the ads are happened in many marketing events and programs. It has been considered as the effective approach to attract consumers attention and the message would be easy to be remembered and internalized in the memory. This phenomena also had happened in Indonesia where tv ads content sexual images which had caused controversy and rejection among the consumers and authorities. There were feminism issues about the women that should not be treated as the sexual object. The sample of tv ads which content sexual images in Indonesia was the ad of Condom Sutra performing four artist playing bilyard. This tv ads had appeared on the national tv channel in 2015 and had a lot of sexual languages, images and the moves that could be considered as pornographic actions. There were several researchs had been conduct on this particular issue but this research presents the analysis through different point of view. Therefore the semiotic analyzing methods introduced by Roland Barthes is applied in this research paper. The observations methods and qualitative research approach are part of the analyzing process to reach the objective and conclude the phenomena.
\end{abstract}

Keywords : condom sutra, tv ads, sexual image.

\section{Pendahuluan}

Televisi dan iklan di dalamnya merupakan salah satu alat komunikasi pemasaran yang efektif untuk memasarkan suatu produk dan membangun citra perusahaan. Besarnya jangkauan televisi dapat menjangkau jutaan pemirsa dalam waktu yang singkat dan bersamaan. Dengan menonton iklan televisi, pemirsa dengan mudah dapat mengingat bahkan menirukan narasi, lagu pengiring, musik latar ataupun gerakan dan tarian yang muncul pada iklan tersebut. Terlebih lagi di era maraknya pengguna media sosial. Iklan yang unik dapat menjadi viral dalam waktu singkat yang menjangkau mayoritas pasar konsumen.

Pembuat iklan harus mampu memastikan bahwa publik mampu menyimpulkan pesan yang disampaikan melalui makna denotasi dan konotasi serta 


\section{Jurnal Bisnis dan Kajian Strategi Manajemen}

Volume 3 Nomor 1, 2019

ISSN : 2614-2147

komunikasi non verbal sesuai dengan harapan dari pembuat iklan tersebut. Oleh karenanya iklan harus mampu membaca suatu konvensi sosial dan budaya serta kebiasaan komunitas yang menjadi target pasar (Hoed, 2014:11).

Jalan pikiran manusia telah mampu dikuasai melalui siaran televisi dengan pola membangun teater dalam cara berpikir manusia sebagaimana gambaran yang muncul dalam iklan di televisi. Realitas tersebut tercipta dari suatu model produksi yang oleh Baudrillard (Piliang,1998:228) disebut dengan istilah simulasi, yaitu penciptaan model-model nyata yang tanpa asal usul atau realitas di awal. Kondisi ini juga sering disebut (hyper-reality). Dalam model simulasi ini, publik dijebak dalam suatu ruang, yang dianggap sebagai realita, meskipun pada hakekatnya adalah khalayan belaka (Bungin, 2006: 221-222).

Publik seakan-akan tidak menyadari jika kesadaran yang dimiliki dan dirasakan merupakan suatu kesadaran semu yang diciptakan oleh rekayasa media. Salah satu bentuknya adalah penggunaan unsur-unsur sensualitas dalam proses pendekatan komunikasi yang dilakukan melalui iklan televisi.

Eksploitasi sensualitas wanita sering muncul dalam bentuk komunikasi non verbal. Komunikasi non verbal ini dapat berbentuk gerak isyarat, bahasa tubuh, ekspresi wajah, intonasi bahasa maupun simbol lainnya seperti cara berpakaian dan riasan yang dipakai (Verderber, 2005).

Pendekatan komunikasi pemasaran dengan menggunakan unsur sensualitas bukanlah hal baru dalam dunia periklanan televisi. Para ahli komunikasi dan pemasaran menyatakan bahwa pendekataan seksualitas dalam komunikasi pemasaran telah terjadi di akhir abad ke-19 yaitu penggunaan gambar-gambar yang mengandung unsur pornografi untuk mendekati konsumen.

Sensualitas wanita merupakan hal yang menarik untuk dieksploitasi oleh pelaku periklanan dan media guna menarik perhatian target audiens. Ida dan Surya (2002) mengatakan seringkali unsur sensualitas ditampilkan dengan meletakkan atribut-atribut tertentu pada seorang model wanita, misalnya pakaian yang seksi serta transparan. Dikarenakan sifatnya yang visual, maka ia akan mampu membangkitkan gairah bagi target audiens yang melihat dan akhirnya tertarik untuk memperhatikan informasi yang disampaikan hingga mengkonsumsi produk yang diiklankan.

Masih berdasarkan pendapat Ida dan Surya (2002) bahwa konsep sensualitas yang ada di berbagai media tidak didefiniskan dengan definisi yang tegas dan jelas. Namun demikian, publik secara umum menganggap bahwa sensualitas adalah aksi yang sengaja dimunculkan demi membangkitkan imajinasi seks bagi yang melihatnya. Pakaian ketat dan minim, menerawang serta terbuka adalah bentukbentuk sensualitas yang umum hadir di ruang publik terutama media massa. Konsep ini berhubungan erat dengan kemampuan panca indera dalam menangkap objek tersebut. Secara umumnya objek dalam bentuk audiovisual mempunyai pengaruh paling kuat dalam membangun konsep seksualitas dan sensualitas tersebut.

M Suyanto menyampaikan hal yang sama dalam bukunya berjudul "Strategi 


\section{Jurnal Bisnis dan Kajian Strategi Manajemen}

Volume 3 Nomor 1, 2019

ISSN : 2614-2147

Perancangan Iklan Televisi Perusahaan Top Dunia”. Dia menyampaikan bahwa seksualitas mempunyai kemampuan menarik perhatian awal dengan sangat kuat dan dapat bertahan dalam kurun waktu yang lama. Efek seksualitas mampu mengingatkan kembali inti informasi serta emosional respon. Suyanto (2005:108) menggambarkan bahwa daya tarik seks seringkali memakai wanita dengan penampilan yang atraktif dan pose yang provokatif.

Fakta kuatnya daya tarik seks dalam menarik perhatian konsumen seringkali menginspirasi para pembuat iklan dengan memasukkan berbagai bentuk unsur seksualitas dalam iklan yang mereka hasilkan terutama iklan televisi. Aspek etika, moral dan nilai sosial budaya yang ada dalam masyarakat seringkali dikesampingkan, padahal ini merupakan bagian utuh dari etika bisnis yang patut untuk selalu seiring sejalan dengan aturan hukum dan etika yang berlaku di masyarakat. Sebagian mereka beragumen bahwa etika iklan bukanlah etika bisnis, karena perbedaan latar belakang dan implementasinya. Iklan dianggap sebagai representasi dari kreativitas dan seni yang perlu ruang yang lebih bebas dalam menghasilkan sebuah karya tanpa batasan-batasan ketat sebagaimana batasan dalam mengatur etika bisnis. Alasan-alasan ini seringkali melatarbelakangi munculnya iklan-iklan yang mengandung unsur pornografi.

Kondisi ini mengakibatkan munculnya berbagai program iklan televisi yang tidak mendidik dan cenderung eksploitatif (Sumartono, 2002: 130). Beberapa iklan televisi muncul dengan adegan tidak etis yang menampilkan wanita-wanita seksi berpakaian tidak senonoh dengan memperlihatkan bentuk tubuhnya, ataupun gerakan-gerakan yang dapat dikategorikan sebagai gerakan erotis. Pada akhirnya iklan-iklan tersebut memperlihatkan secara lugas eksploitasi terhadap wanita sebagai objek seksual yang sangat merendahkan harkat dan derajat wanita itu sendiri. Hal ini sebagaimana disampaikan oleh (Widyatama, 2006: 7) bahwa wanita banyak direpresentasikan dalam stereotip yang cenderung merendahkan posisi wanita di hadapan laki- laki, sebagai objek komoditas, serta cenderung dieksploitasi atas potensi fisiknya semata.

(Bungin, 2006: 355) mengatakan bahwa wanita dieksploitasi dalam berbagai bentuk penyampaian informasi di media massa bukan saja karena para wanita rela diperlakukan demikian, tetapi juga disebabkan oleh pengaruh tekanan kelas sosial. Sehingga terlepas dari kemauan atau ketidakmauannya, ia menjadi bagian dari kebutuhan kelas sosial tersebut. Suatu fakta yang masih terjadi di berbagai kelompok sosial dan budaya, bahwa wanita masih kerap dipersepsikan sebagai subordinat dominasi para lelaki sehingga mereka dipaksa mengikuti keinginan kelompok sosial tersebut.

Dalam berbagai iklan yang menonjolkan unsur sensualitas, wanita hanya ditampilkan untuk memenuhi keinginan dan kesenangan lelaki, cenderung mengabaikan atau bahkan membenarkan munculkan kekerasan ataupun pelecehan, serta mengidentikkan gerakan wanita dan tingkah lakunya sebagai bahan candaan. 


\section{Jurnal Bisnis dan Kajian Strategi Manajemen}

Volume 3 Nomor 1, 2019

ISSN : 2614-2147

(Lin: 2008). Wanita seringkali dipaksa untuk meyakini dan memerankan peran dimana penampilan begitu dielu-elukan dan dianggap sebagai unsur terpenting, sedangkan pemikiran mereka dianggap sesuatu yang tidak signifikan. Posisi wanita yang tidak memiliki kompetensi dan penuh ketidakberdayaan sebagai suatu hal yang normal (Boyer, 1986). Kebalikan dengan posisi wanita di layar kaca, kebanyakan pria ditampilkan sebagai sosok yang sangat cakap dan cerdas (Boyer, 1986).

Tubuh wanita seringkali menjadi objek iklan. Setiap bagian dari tubuh wanita dikembangkan sebagai komoditas pasar baik yang berkaitan langsung dengan kebutuhan wanita maupun yang tidak. Dalam konteks ini wanita dihargai dan juga dijatuhkan karena tubuhnya. Tubuh wanita didefinisikan sebagai pembawa sensualitas yang mampu membangkitkan imaginasi seksual mengundang hasrat seks lelaki.

Sensualitas berkaitan langsung dengan inderawi. Hal ini tercermin dari asal katanya yaitu "sense" yang bermakna "rasa". Oleh karenanya dalam iklan sensualitas wanita dimanifestasikan dalam bentuk fisiknya maupun aktivitasnya. Bentuk tubuh, cara berpakaian, aksesoris, maupun parfum yang dipakai dapat didefiniskan sebagai bentuk nyata sensualitas seorang wanita (Padila, 2013). Salah satu iklan televisi yang menggunakan sensualitas wanita sebagai daya tariknya adalah iklan Kondom Sutra yang sempat tayang di TransTV pada tahun 2015 dan kemudian dihentikan setelah mendapat teguran keras dari KPI melalui surat dengan nomor 340/K/KPI/04/15.

Iklan tersebut diatas mengandung unsur sensualitas berlebihan, tidak senonoh dan cenderung mengandung unsur pornografi. Penelitian ini menggunakan analisis semiotika guna mengeksplorasi maka bahasa dan sosial yang mucul dalam iklan tersebut, baik non verbal ataupun verbal. Metode analisis semiotika yang dipakai selaras dengan prinsip analisis semiotika melalui gagasan two order of signification yang dicetuskan oleh Roland Barthes. Ia mendeskripsikan penggunaan kekuatan semiotika guna membongkar struktur makna yang terembunyi dalam tontonan, pertunjukan sehari-hari dan konsep-konsep umum (Danesi,2010:12).

\section{Metodologi Penelitian}

Penelitian ini dilakukan dengan metode kualitatif yaitu metode analisis semiotika yang dikembangkan oleh Roland Barthes. Metode penelitian kualitatif adalah sebuah metode yang menekankan pada unsur pemahaman secara mendalam terhadap suatu isu atau pokok bahasan. Penelitian kualitatif juga sering dimaknai sebaga penelitian yang bersifat deskriptif dan cenderung menekankan pada kekuatan analisis serta lebih fokus pada makna dan proses. Tujuan dari metodologi penelitian ini adalah untuk memahami secara komprehensif suatu permasalahan yang diteliti atau dikaji. Data yang dihasilkan mayoritas berupa kata ataupun gambar-gambar dan sangat sedikit data dalam bentuk perhitungan kuantitatif atau angka. Adapun metode analisis semiotika Roland Barthes diaplikasikan guna memahami secara lengkap representasi sensualitas yang ditampilkan pada iklan 


\section{Jurnal Bisnis dan Kajian Strategi Manajemen}

Volume 3 Nomor 1, 2019

ISSN : 2614-2147

Kondom Sutra di televisi. Pengkajian juga dilakukan terhadap proses pembentukan makna semiotika yang bersifat disengaja dan memiliki tujuan tertentu.

Dalam penelitian ini, data penelitian dikumpulkan dengan mengamati melalui observasi via channel youtube dikarenakan iklan ini tidak lagi ditayangkan di televisi saat ini. Data lainnya dikumpulkan dengalan melakukan studi kepustakaan yaitu mengumpulkan data dengan menelaah berbagai literatur bacaan seperti jurnal, buku-buku terkait, sumber informasi dari webistes di internet, dan karya-karya ilmiah lainnya yang dapat dijadikan rujukan.

Pengkajian iklan Kondom Sutra yang dilakukan dalam penelitian ini memakai metode analisis semiotoka oleh Roland Barthes guna memahami aspekapek sensualitas yang ada di dalam iklan tersebut, serta mengurai data melalui analisis arti konotasi, mitos dan denotasi.

\section{Kerangka Teori}

Istilah komunikasi atau communication berasal dari kata communicatio, dan bersumber dari kata aslinya yaitu communis yang memiliki arti sama atau serupa. Sama dalam hal ini berarti sama makna. Artinya jika ada dua individu yang sedang berdialog atau berbicara, maka proses komunikasi hanya akan terlaksana andai keduanya memiliki kemampuan yang sama untuk memaknai perihal yang sedang diperbincangkan. (Effendy, 2007:9)

Pengertian di atas merupakan makna dasar, dikarenakan semakin majunya teknologi komunikasi, ilmu tentang komunikasi juga berkembang mengikuti perkembangan zaman dan teknologi terkait. Makna komunikasi pun menjadi semakin luas sampai menyentuh unsur budaya. Berdasarkan pendapat John Fiske, dalam bukunya berjudul Cultural Communication: Sebuah Pengantar Paling Komprehensif, ia mencermati eratnya kaitan antara komunikasi dan budaya dalam membangun hubungan dan kehidupan antar sesama manusia di tengah kemajuan teknologi komunikasi massa, khususnya internet, televise dan media sosial. Ia menyampaikan bahwa komunikasi merupakan hal vital bagi kehidupan dan budaya manusia. Tanpa komunikasi, kebudayaan menjadi hal yang mustahil untuk dibangun dan dikembangkan. Oleh karenanya, komunikasi akan terikat dengan studi budaya dan terintegrasi dengannya. (Fiske, 2004: IX).

George E. Belch dan Michael A. Belch. dalam Morrisan M.A. (2010:14) menyatakan bahwa advertising dapat dimaknai sebagai salah satu bentuk komunikasi nonpersonal tentang suatu lembaga organisasi, produk, jasa, atau pemikiran yang dibayar oleh suatu penyandang dana yang jelas dan diketahui.

Pariwara atau iklan televisi terdiri dari audio dan visual, sebagaimana disampaikan oleh Morissan (2010:365) yang menyebutkan bahwa dua hal tersebut haruslah bekerja bersama guna menghasilkan efek dan juga menyampaikan informasi iklan untuk para audiens.

Elemen pertama dikenal sebagai elemen visual yaitu elemen yang sangat 


\section{Jurnal Bisnis dan Kajian Strategi Manajemen}

Volume 3 Nomor 1, 2019

ISSN : 2614-2147

dominan pada pariwara televisi sehingga harus punya kekuatan untuk menarik perhatian audicences sekaligus ide dan informasi yang terkandung dalam pariwara tersebut dapat tersampaikan dengan baik dan diterima oleh target audiences. Jika elemen pertama telah mencapai target yang diharapkan maka pekerjaan di elemen berikutnya akan lebih mudah.

Elemen kedua dikenal dengan elamen audio. Elemen audio dari suatu pariwara tv adalah musik, suara dan efek. Musik juga merupakan elemen penting untuk menarik perhatian, penyampai informasi dan membangun product image. Wanita juga marak dieksploitasi dalam iklan televisi untuk membangun product image sehingga menimbulkan citra negatif. Kaum hawa ini memiliki nilai ekonomis yang tinggi dalam industri periklanan dan pertelevisian. Oleh karenanya dimanfaatkan untuk keuntunan bisnis dan suatu kepentingan.

Pariwara televisi seringkali menempatkan perempuan pada posisi sebagai objek fantasi seksual. Walaupun dalam konteks bahasa terselubung namun dipahami memiliki makna konotatif yang menempatkan perempuan pada posisi yang tidak semestinya. Misalkan saja iklan televisi Pindy Mint dengan tagline iklannya "dingindingin empuk", iklan televisi produk kopi Torabika dengan tagline "pas susunya", dan iklan produk Sidomuncul dengan tagline "puasss rasanya".

Semiotika merupakan suatu bidang kajian dan analisis guna mengkaji apa yang disebut sebagai sign dan meaning (Sobur, 2012). Suatu sign atau tanda menunjuk pada objek tertentu selain diri sendiri dan meaning atau makna adalah yang menghubungkan antara objek dan tanda (Hartoko dan Rahmanto, 1986:131). Kata "semiotik" berasal dari bahasa Yunani yaitu 'semeion" yang maknanya adalah "tanda" (Sudjiman dan Van Zoest , 1996:vii) atau sebagaimana disampaikan oleh Cobley \& Jansz (1999) yang maknanya "penafsir tanda".

Pada tahun 1916 seorang ahli bahasa bernama Ferdinand de Saussure menyampaikan pendapatnya bahwa melihat tanda sebagai titik temu antara makna dan bentuk. Istilah yang ia pakai yaitu penanda atau signifiant, bagi suatu tanda, dan pertanda atau signifier bagi maknanya (Hoed, 2015:3). Pada hakekatnya, hal yang didapatkan pada seluruh definisi yang dimaksud yaitu kata tanda. Pada riset ini makna semiotik Saussure dipakai untuk mendukung dan mempertegas makna yanga ada dalam tanda dalam pariwara televisi Shimizu.

Roland Barthes meneruskan konsep pemikiran dari Saussue. Saussure berminat menelaah lebih lanjut metode kompleks terbentuknya kalimat serta cara penentuan makna oleh berbagai bentuk kalimat. Namun kurang tertarik membahas bahwa suatu kalimat bisa saja memiliki makna berbeda atau diartikan berbeda karena perbedaan situasi atau oarang yang menyampaikan maupun orang yang menerima. Roland Barthes melanjutkan konsep pemikiran itu dengan menitikberatkan pada interaksi antar teks bahasa dengan pengalaman kehidupan pribadi dan budaya pemakainya, hubungan antar sesuatu peristiwa yang diharapkan dan yang dialami oleh pemakainya. Gagasan yang dikemukakan oleh Barthes ini kemudian dikenal 


\section{Jurnal Bisnis dan Kajian Strategi Manajemen}

Volume 3 Nomor 1, 2019

ISSN : 2614-2147

dengan sebutan "order of signification" (Krisyantono, 2009:270).

Roland Barthes (1915-1980) juga memakai konsep signifiant-signifie dan hadir dengan teori tentang makna konotasi. Perbedaan utamanya yaitu Barthes menitikberatkan teori yang ia kemukakan kepada mitos dan bukan kepada individu tetapi pada kelompok masyarakat tertentu. Barthes menyampaikan bahwa semua hal yang dinilai kewajaran dalam suatu budaya masyarakat merupakan hasil akhir dari suatu proses konotasi. Beda lainnya yaitu pada aspek titik berat di unsur penandaan konteks. Barthes memakai ungkapan ekspresi (yaitu bentuk dan ekspresi itu sendiri bagi signifiant) dan contenu (yaitu isi bagi signifie). Secara teori bahasa merupakan suatu sistem statis, seperti ketika seseorang menyebut meja hijau maka secara bahasa memiliki arti meja yang warnanya hijau. Ini yang disebut dalam istilah bahasa sebagai $1^{\text {st }}$ order. Akan tetapi bahasa yang berfungsi sebagai $2^{\text {nd }}$ order mengizinkan kata meja hijau mempunyai arti "persidangan". Hal inilah yang disebut konotasi (Padila, 2013:32).

\section{Pembahasan}

Iklan Kondom Sutra yang vulgar dan tidak senonoh ini pernah ditayang di stasiun TRANSTV pada tahun 2015. Iklan ini telah mendapatkan peringatan keras dari KPI melalui surat bernomor 340/K/KPI/04/15. Surat ini ditujukan kepada TRANSTV selaku stasiun televisi yang menayangkan iklan tersebut untuk dapat segera menghentikan penayangannya.

KPI mengatakan, berlandaskan Pasal 43 Pedoman Perilaku Penyiaran dan Pasal 58 Standar Program Siaran KPI Tahun 2012 maka siaran iklan diharuskan mematuhi Etika Pariwara Indonesia (EPI). Pada ketentuan ini yaitu pada huruf A poin 1.7 tertulis bahwa sebuah iklan wajib menghargai dan melestarikan normanorma agama dan budaya di Indonesia. Berbagai norma yang berkembang di Indonesia baik norma agama maupun budaya begitu menjunjung tinggi nilai kesopanan. Oleh karenanya tampilan sensualitas wanita dalam berbagai bentuknya tidak selaras dengan nilai luhur budaya bangsa dan menghadirkan pengaruh negatif pada masyarakat umum terutama para generasi muda. KPI juga menambahkan sesuai ketentuan EPI huruf A poin 2.8.2 bahwa iklan kondom dan beberapa produk laiinya yang bersifat intim harus ditampilkan sesuai aspek kepantasan dan jam tayang yang memang khusus diperuntukan bagi orang dewasa.

KPI Pusat memperingatkan seluruh pengelola stasiun televisi bahwa adegan pariwara Kondom Sutra yang telah tayang ini melanggar aturan hukum yang menyebutkan bahwa iklan dilarang menayangkan hal-hal yang berbau erotisme baik visual maupun verbal. Pelanggaran terhadap aturan ini dapat berujung pada sanksi berupa dihentikannya penayangan iklan tersebut di seluruh stasiun televisi. Pada bagian berikut ini akan dicoba untuk mengenalisa secara lebih mendalam bagianbagian dari iklan Kondom Sutra yang mengeksploitasi unsur sensualitas wanita.

Secara umum deskripsi iklan ini menampilkan tiga orang wanita berpakaian 


\section{Jurnal Bisnis dan Kajian Strategi Manajemen}

Volume 3 Nomor 1, 2019

ISSN : 2614-2147

sangat minim dan ketat sebagai pemeran utama. Ketiga wanita ini digambarkan sebagai wanita pendamping meja bilyard di sebuah tempat permainan bilyard. Iklan ini juga didukung oleh bintang iklan lainnya yaitu seorang pria yang berperan sebagai pemain bilyard.

Iklan berdurasi 30 detik ini dimulai dengan adegan tampilan suasana meja permainan bilyard. Adegan diawali dengan seorang pria pemain bilyard yang menunjukkan keterampilan luar biasa dalam hal ketepatan dan kekuatan dalam bermain bilyard. Tiga wanita pelayan meja tampak berdiri seksi menghadap meja bilyard. Mereka tampil dengan pakaian yang sangat minim dan unsur sensualitas yang tinggi. Ketiga wanita ini menunjukkan kekaguman akan skill yang dimiliki oleh lelaki pemain bilyard. Tampilan wajah erotis, fokus kamera yang menunjukkan bentuk tubuh yang sangat vulgar, serta pegangan pada stick bilyard yang dapat diinterpretasikan sebagai suatu aksi yang berkonotasi seksual.

Adegan selanjutnya kembali menampilkan kemampuan lelaki pemain bilyard yang hanya dengan sekali pukulan berhasil memasukkan semua bola bilyard ke dalam lubangnya. Kemudian sang pemain bertanya dengan nada bangga "still want some more" yang dalam bahasa Indonesia dapat berarti "masih mau lagi?". Pertanyaan ini dijawab dengan adegan para wanita pelayan meja bilyard memegang bola bilyard yang terlihat dikuatkan aspek sensualitasnya. Ketiga wanita ini mengatur kembali bola bilyard dan secara kompak berkata "so we can play longer" yang dalam bahasa Indonesia dapat diartikan "(iya) biar bisa main lebih lama”, yang kemudian dijawab "Ok" oleh lelaki pemain bilyard.

Adegan berikutnya menampilkan kemampuan lelaki tersebut bermain bilyard dengan berbagai posisi bola diselingi dengan gambaran wajah wanita pelayan meja menunjukkan kekaguman dengan tampilan wajah menunjukkan gairah dan hasrat. Tiga wanita tersebut tampak mendekati sang lelaki dan mendekatkan wajah nya ke wajah sang lelaki dan disertai senyuman menggoda.

Iklan tersebut kemudian dilanjutkan dengan tampilan dua wanita di sekeliling meja dengan pakaian minim dan seorang wanita lainnya dalam posisi akan memukul bola bilyard dimana lelaki berada di belakang sang wanita dengan posisi yang sangat dekat terlihat memberikan pelajaran memukul bola dengan tepat dan kuat. Lalu muncul kalimat "only with Sutra OK the "action" is longer" atau dalam bahasa Indonesia dapat diartikan "hanya dengan Sutra OK "aksi" bisa lebih lama". Kemudian muncul adegan dimana wanita tersebut menjadi sangat mahir memainkan bilyard dan terlihat mampu memasukkan bola bilyard sekalipun dalam posisi bola yang sulit. Adegan ini diikuti dengan munculnya kalimat "whatever the position, it's $O K$ and $O K$ and $O K$ !" sambil menampilkan posisi wanita yang berdiri puas dengan busana yang sangat vulgar.

Adegan dilanjutkan dengan sang lelaki yang kembali menunjukkan kelihaiannya dalam bermain bilyard. Iklan ini ditutupi dengan tampilan tiga wanita yang menyusun tiga rangkaian bola dan menantang lelaki tersebut bermain. Posisi 


\section{Jurnal Bisnis dan Kajian Strategi Manajemen}

Volume 3 Nomor 1, 2019

ISSN : 2614-2147

berdiri, tampilan pakaian dan gerakan mencakar seperti harimau muncul sebagai akhir dari adegan yang kemudian ditutup oleh tampilan layar bertuliskan kalimat "Sutra OK, lebih lama lebih Ok".

Iklan Kondom Sutra ini memiliki jalan cerita dengan konsep analogi antara kemampuan dan kehebatan memainkan stick bilyard dan memasukkan bola ke dalam lubang dengan kemampuan dan kehebatan pria dalam urusan seks. Hal ini tampak jelas ketika iklan diawali dengan adegan keahlian lelaki bermain bilyard dan tampilan wanita berpakaian sangat minim dan seksi dengan tampilan wajah penuh hasrat. Situasi ini diikuti oleh lelaki pemain bilyard yang bertanya "“"still want some more".

Secara denotasi adegan dan kalimat ini bermakna kepuasan seorang wanita dan sang, dengan konteks yang sangat umum. Dalam bahasa formal bahasa tubuh para wanita pelayan bilyard tersebut dapat disusun dengan narasi "Saya merasakan sensasinya". Adapun bahasa sang lelaki dapat ditulis "apakah menginginkannya lagi”. Namun secara konotasi, kalimat ini mengandung makna yang sangat vulgar. Terutama ketika kalimat tersebut diucapkan oleh lelaki kepada wanita yang mengenakan pakaian sangat minim dan seksi dengan aura wajah yang menunjukkan hasrat dan nafsu seksual. Ketika kalimat tersebut muncul dengan deskripsi adegan tersebut diatas maka makna konotasi yang muncul adalah kondisi keperkasaaan pria dimana ia sangat ahli dalam memberikan kepuasan seksual kepada pasangannya sehingga menanyakan apakah pasangannya masih ingin melakukannya lagi. Pertanyaan ini dijawab dengan jawaban yang kembali sangat kuat unsur sensualitasnya "so we can play longer".

Pada kenyataannya tidak ada korelasi langsung antara bilyard dengan aktivitas seks pasangan. Namun dalam hal ini pembuat iklan seperti mencoba untuk membangun rasa penasaran para pemirsa televisi untuk mengetahui kelanjutannya. Adegan sensual di tempat permainan bilyard dijadikan penarik utama untuk mengenal lebih jauh produk yang akan dipromosikan kepada konsumen.

Adegan selanjutnya adalah wanita pelayan dengan pakaian seksi dan minim yang juga menjadi lihai bermain bilyard. Adegan ini juga memperlihatkan para wanita yang memegang dan menyusun bola bilyard dengan sudut dan cara pengambilan gambar yang cukup erotis. Kemudian saat bermain bilyard, sang wanita berhasil memukul dan memasukkan bola dengan berbagai posisi yang terlihat cukup sulit.

Secara denotasi hal ini adalah suatu hal biasa yang dilakukan oleh seorang wanita pelayan bilyard yaitu menyusun bola bilyard dan juga hal yang biasa juga suatu adegan wanita bermain bilyard. Namun secara konotasi ini bisa diartikan juga bahwa adegan wanita yang sangat lihai dalam urusan seksual. Hal ini tersirat dari pakaian seksi yang ia kenakan dan gestur tubuh yang ia tampilkan saat ini memegang bola bilyard dan berbagai posisi yang ia lakukan saat memukul bola. Hal ini secara konotasi dimaknai sebagai kemampuan untuk melakukan berbagai posisi saat 


\section{Jurnal Bisnis dan Kajian Strategi Manajemen}

Volume 3 Nomor 1, 2019

ISSN : 2614-2147

berhubungan dengan pasangan. Terlebih lagi, adegan tersebut diikuti oleh kalimat "only with Sutra OK the "action" is longer" yang secara konotasi dimaknai sebagai kegiatan bercinta yang bisa dilakukan dalam durasi lama karena kehebatan produk Kondom Sutra OK yang membuat wanita dapat mengekplorasi berbagai posisi. Hal Makna konotasi ini diperkuat dengan munculnya kalimat "whatever the position, it's $O K$ and $O K$ and $O K ! "$ di akhir adegan iklan.

Kemudian jalan cerita berlanjut ke adegan lelaki yang hebat bermain bilayrd dan ditutup dengan tampilan para wanita menyusun tiga rangkaian bola bilyard dan menantang lelaki tersebut bermain. Posisi tubuh, mimik wajah dan gerakan mencakar seperti harimau hadir sebagai penutup dari adegan yang kemudian diakhiri oleh tampilan kalimat "Sutra OK, lebih lama lebih Ok".

Alur cerita ini berusaha meyakinkan konsumen yang menonton iklan ini untuk mengambil sebuah kesimpulan bahwa baik secara denotasi maupun konotasi bahwa produk Kondom Sutra memberikan keuntungan yang sangat besar bagi lelaki dalam memainkan perannya untuk memberikan kepuasan kepada pasangannya. Di saat yang sama kehadiran kondom Sutra yang membuat durasi bercinta menjadi lama sangat memuaskan wanita karena denganya wanita menjadi lihai dan dapat mengeksplorasi berbagai posisi saat bersama pasangannya. Pesan-pesan ini secara implisit dan konotatif dihadirkan melalui bentuk berbagai benda di dalam iklan yang secara mitos dimaknai memiliki hubungan makna dengan persepsi orang terhadap aktivitas seksual. Benda tersebut antara lain permainan bilyard berikut segala pernak pernik nya seperti tongkat, bola ataupun lubang dan meja bilyard. Posisi tubuh pemain bilyard saat bermain semakin memperkuat unsur sensualitas yang menjadi menu utama untuk menarik perhatian konsumen.

Kata-kata "only with Sutra", "It's Ok", "Sutra Ok" merupakan repetisi untuk memperkuat internalisasi pesan verbal kepada konsumen untuk mendukung pesan yang disampaikan melalui gambar dan gerakan. Pada tahap inilah konsumen diharapkan telah memiliki suatu keyakinan terhadap keunggulan produk kondom Sutra sebagai solusi terbaik untuk meningkatkan performa hubungan dan gairah bersama pasangan.

\section{Kesimpulan}

Iklan televisi telah menjadi sebuah bisnis besar dimana kapitalisme menunjukkan taringnya hingga pada beberapa kasus menabrak batas hukum dan moralitas. Penelitian ini menyimpulkan bahwa tubuh wanita telah dijadikan komoditas untuk meraih keuntungan dengan mengabaikan norma yang berkembang di tengah masyarakat. Sensualitas tubuh wanita dianggap sebagai magnet paling kuat untuk menarik perhatian pasar pompa air yang secara umum didominasi oleh kaum pria. Pesan iklan diasumsikan dapat melekat kuat di ingatan konsumen dengan memanfaatkan naluri dasar pria yang tertarik akan seksualitas wanita, sehingga menguatkan pesan utama yang akan disampaikan oleh iklan tersebut. 


\section{Jurnal Bisnis dan Kajian Strategi Manajemen}

Volume 3 Nomor 1, 2019

ISSN : 2614-2147

Asosiasi fungsi dan kemampuan produk dengan fungsi dan aktivitas seksual juga sangat terasa dari pemilihan kosa kata "play longer" dan "whatever the position, it's $O K$ and $O K$ and $O K$ !" serta visualiasi model yang membawakan pesan yaitu pakaian dan gerakan yang ditampilkanya. Konsep asosiasi ini membangkitkan sugesti seksual yang secara etika tidak sesuai dengan norma dan aturan yang ada. Terlebih lagi karena jadwal tayangnya pada waktu-waktu dimana anak dibawah umur masih sangat mungkin untuk menonton iklan tersebut.

Beberapa hal berikut menjadi kesimpulan dan fakta-fakta sensualitas wanita telah menjadi ujung tombak dalam implementasi strategi komunikasi pemasaran produk Kondom Sutra Ok, yaitu :

- Terdapat makna tersembunyi dalam iklan Kondom Sutra yang menggambarkan persepsi dan harapan umum di masyarakat tentang sensualitas yang direpresentasikan secara jelas oleh profil wanita seksi, dan hal yang mampu membuat ia bergairah ataupun bahagia.

- Figur wanita cenderung tereduksi martabatnya karena tingkah lakunya terutama dari segi pakaian yang ia kenakan serta gerakan tubuh yang ia tampilkan.

- Seks dimunculkan sebagai sesuatu hal yang paling utama dalam suatu hubungan, dan kehebatan hubungan itu kemudian dihubungkan dengan kemampuan produk Kondom Sutra yang digambarkan dalam makna adegan kehebatan permainan bilyard.

- Mitos bahwa wanita akan ceria dan bahagia jika dia terpuaskan secara seksual begitu ditonjolkan dalam iklan ini. Sehingga konsumen diharapkan mampu menghadirkan kebahagiaan yang sama. Oleh karenanya mucul produk Kondom Sutra sebagai alternatif terbaik untuk kebahagiaan dan kepuasan dalam hubungan dengan pasangan.

\section{Daftar Pustaka}

Hoed, Benny H. 1994. Dampak Komunikasi Periklanan, Sebuah Ancangan dari Segi Semiotika. SENI (Jurnal Pengetahuan dan Pencipta Seni). Yogyakarta: BPISI.

Lin, Ma. 2008. The Representation of the Orient in Western Women Perfume Advertisiment: A Semiotic Analysis. Intercultural Communication Studies: Beijing Foreing Studies University.

Basow, S.A. 1992. Gender stereotypes and roles,3rd ed. Pacific Grove, CA: Brooks/Cole Publishing Company 
Boyer, P.J. 1986. TV turns to the hard boiled male. New York Times, February 16, p.H1 and $\mathrm{H} 29$.

Bungin, Burhan. 2006. Sosiologi Komunikasi. Jakarta: Kencana.

Danesi, Marcel. 2010. Pengantar Memahami Semiotika Media. Yogyakarta: Jalasutra.

Effendy, Onong Uchjana. 2007. Ilmu Komunikasi: Teori dan Praktek. Bandung: hRemaja Rosda Karya.

Fiske, John. 1997. "The Codes of Television" dalam Media Studies; A Reader, edited by Paul Marris dan Sue Thornham. Edinburg: Edinburg University Press.

Ida, Rachmah \& Surya, Yuyun Izzati. 2002, Politik Tubuh Dan Sensualitas Wanita: Diskursus Media Terhadap Fenomena Goyang Penyanyi Dangdut Wanita, Universitas Airlangga, Surabaya.

Kasali, Rhenald. 1995. Manajemen Periklanan, Konsep, dan Aplikasinya di Indonesia. Jakarta: Pustaka Utama Grafity.

Krisyantono, Rahmat. 2009. Teknik Praktis Riset Komunikasi. Jakarta: kencana Prenada Media group.

M.A, Morrisan. (2010). Periklanan: Komunikasi Pasar Terpadu. Jakarta: Kencana Prenada Media Group

Mulyana, Deddy. 2004. Ilmu Komunikasi Suatu Pengantar. Bandung: Remaja Rosdakarya

Mulyana, Deddy. 2004. Komunikasi Efektif: Suatu Pendekatan Lintas budaya. Bandung: Remaja Rosdakarya.

Noviani, Ratna. 2002. Jalan Tengah Memahami Iklan. Yogyakarta: Pustaka Pelajar.

Sayekti, Tyas. 2009. Komodifikasi Aspek Seksualitas Wanita dalam Film Mengejar Mas Mas. Fakultas Ilmu Komunikasi Universitas Mercu Buana, Jakarta.

Sobur, Alex. 2012. Analisis Teks Media: Suatu Pengantar untuk Analisis Wacana, Analisis Semiotik, dan Analisis Framing. Bandung: Remaja Rosdakarya.

Sumartono. 2002. Terperangkap dalam Iklan, Meneropong Imbas Pesan Iklan Televisi. Bandung: Alfabeta.

Susanti, Dede. 2016. Analisis terhadap Komodifikasi Tubuh Wanita dalam Iklan Es Krim Magnum Versi Pink \& Black. Program Studi Komunikasi dan Penyiaran 
Jurnal Bisnis dan Kajian Strategi Manajemen

Volume 3 Nomor 1, 2019

ISSN : 2614-2147

Islam, Fakultas Dakwah. IAIN, Purwokerto.

Suyanto, M. 2005. Strategi Perancangan Iklan Televisi Perusahaan Top Dunia. Yogyakarta: Penerbit Andi.

Verderber, Rudolph F. (2005). "Chapter 4: Communicating through Nonverbal Behaviour". Communicate! (edisi ke-edisi ke-11). Wadsworth. ISBN 0-534$\underline{73936-4}$ 